\title{
MOLECULAR-GENETIC MODELS FOR PROGNOSIS OF DEVELOPMENT OF TUMORS OF REPRODUCTIVE SYSTEM IN WOMEN WITH FAMILY HISTORY OF CANCER
}

\author{
O.V. Paliychuk, 2, *, L.Z. Polishchuk ${ }^{1}$, Z.I. Rossokha ${ }^{3}$, V.F. Chekhun ${ }^{1}$ \\ ${ }^{1}$ R.E. Kavetsky Institute of Experimental Pathology, Oncology and Radiobiology, NAS of Ukraine, \\ Kyiv 03022, Ukraine \\ ${ }^{2}$ Cherkasy Regional Oncology Center, Cherkasy 18009, Ukraine \\ ${ }^{3} S I$ "Reference Center for Molecular Diagnostics of the Ministry of Health of Ukraine", \\ Kyiv 04112, Ukraine
}

\begin{abstract}
Aim: To develop a prognostic molecular genetic model for assessing the risk of development of benign and malignant tumors of female reproductive organs (FRO) in patients from cancer-affected families. Patients and Methods: The work presents the data on a comprehensive clinical examination of 210 women (90 patients with FRO cancer with aggregation of tumor pathology in families, 65 patients with benign pathology of FRO from cancer-affected families, 55 women - control group of healthy women without family history of cancer). Clinical genealogical analysis, morphological examination of tumors and molecular genetic studies of genomic DNA from peripheral blood and tumors were carried out. Results: It was established that in the families of patients with benign and malignant pathology of FRO, malignant tumors associated with Lynch II syndrome are observed. Based on the analysis of detected ESR-1, CYP 2D6*4 and mutations in BRCA1/2 genes in cancer patients and in patients with benign pathology, molecular genetic models have been developed to assess the individual risk of development of benign and malignant tumors of FRO. It has been established that these molecular genetic models and combinations of gene mutations and gene polymorphisms (SNP) by the intergene interaction that was analyzed, were found to be reliable in assessing the risk of benign and malignant pathology of the mammary gland and ovary. Conclusions: The model, which included the polymorphic variants of the T397C(ESR1)/CYP 2D6*4 genes was of the best predictive accuracy for the evaluation of the risk of benign tumors of the FRO $(71.68 \%)$ and the highest reliability $(p<0.001)$. At the same time, all identified models of intergene interaction in the development of malignant pathology of FRO were reliable, prognostically significant with high reproduction and almost identical accuracy $(65.00-68.23 \%)$. The obtained results indicate a high informativeness of such molecular genetic indices as the polymorphism of ESR1 and CYP 2D6*4 genes and mutations in $B R C A 1 / 2$ genes to assess the risk of benign or malignant tumors of FRO in families of patients with family history of cancer. Key Words: breast cancer, ovarian cancer, pedigree, family cancer syndrome, mutations in BRCA1/2 genes, gene polymorphisms of ESR1, CYP $2 D 6^{*} 4$, molecular genetic models of individual cancer risk.
\end{abstract}

Among the current problems of clinical oncology (screening, prevention, early diagnosis, personalized treatment), one of the topical issues - the individual risk of malignant neoplasms - is of particular interest, although for most of them, including cancer of the female reproductive organs (FRO), risk factors are mostly already defined [1-4].

Meanwhile, breast cancer (BC) and ovarian cancer (OC) still represent the most urgent medical and social problems. This is caused by the high rates of cancer incidence in women in Ukraine and in many economically developed countries. Presently there are developed modern concepts about the molecular genetic nature of malignant growth and the value of hereditary factors in the susceptibility for the development of $\mathrm{BC}$ and $\mathrm{OC}$ [5-7]. At the present time, complex development of theoretical issues of genetics and molecular biology of tumors under the conditions of family history of cancer, hereditary forms of BC,

\footnotetext{
Submitted: November 29, 2017.

${ }^{\star}$ Correspondence: $\quad$ E-mail: oncology@2upost.com Abbreviations used: $\mathrm{BC}$ - breast cancer; BRCA1/2 - breast cancer gene 1/2; CYP 2D6 - cytochrome P450 2D6 enzyme gene; ESR 1 - estrogen receptor 1 (ER-alpha) gene; FRO - female reproductive organs; OC - ovarian cancer; PCR - polymerase chain reaction; SNP - single nucleotide polymorphism.
}

OC, Lynch type I-II syndromes and other oncogenetic syndromes is becoming increasingly relevant [8].

There are already accumulated data on a family aggregation of cancer of common genesis in several generations (cancer of the ovary or mammary gland) or cancer of various genesis ( $\mathrm{OC}$ and $\mathrm{BC}$, uterine and colon cancer, and others), synchronicity or metachronicity of tumors, manifestation of the tumor process in the young age. It has been established that high-penetrant germinal mutations in the tumor suppressor genes $B R C A 1$ and $B R C A 2$ are associated with high risk of hereditary forms of cancer, whereas in normal state these genes are involved in repairing DNA damage and preservation of genetic stability of cells $[9,10]$; also, the polymorphism of other genes could play a role in FRO cancer [11, 12]. The susceptibility for the development of $B C$ and $O C$, hormone dependent tumors, is strongly dependent on the gene polymorphism of ESR1 receptor, which is involved in the hormonal metabolism in normal cells and in the hormonal pathogenesis of a number of malignant tumors $[13,14]$. We can not exclude the role of other genes, including the gene CYP 2D6. Allele variant of this gene, $C Y P 2 D 6 * 4$, contributes to the transformation of tamoxifen in the intermediate active metabolite endoxifen, which determines the effec- 
tiveness of hormonal treatment of BC patients [15]. Therefore, from the point of improving the modern strategy of preclinical early diagnosis of cancer and the introduction of new screening programs for $\mathrm{BC}$ and $\mathrm{OC}$, priority is given to determining the personalized risk of possible malignant growth in women, depending on the family history of cancer and genetic changes in somatic or germinal cells $[9,16,17]$. This research direction is in the focus of the provisions of the NSGC (National Society of Genetic Counselors) and a series of studies in which conducting personalized genetic testing of women, taking into account the frequency of tumor pathology in the family, is the most urgent task for the development of individual genetic screening programs and early diagnosis of FRO cancer and assessment of the risk of its possible development in the descendants of cancer patients [18, 19]. Therefore, the determination of a predisposition to the development of $\mathrm{BC}$ or $\mathrm{OC}$ is an important modern problem of oncogenetics, which requires further research on family cancer history and genetic testing to assess the individual risk of developing cancer in members of families with a burden on cancer history. The risk of re-occurrence of cancer in a family can be determined by the use of already developed models based on the mathematical calculation of risk factors for the occurrence of $\mathrm{BC}$ or $\mathrm{OC}$ that are used in oncology - GailModel (multivariate regression analysis of anamnesis data), ClausModel (segregation analysis of pedigree data, CouchModel tested for mutations in the BRCA1 gene) and several others [20-22].

In the work, we present models of intergene interactions in the development of benign and malignant pathology in people with cancer-affected families based on the analysis of the combination of genetic changes in the genomic DNA of peripheral blood and tumor cells in patients with $\mathrm{BC}$ and $\mathrm{OC}$.

The aim of the work was to develop and test a prognostic genetic model for assessing the risk of developing benign and malignant tumors of FRO in patients with cancer-affected families through a comprehensive analysis of clinical genealogy and molecular genetic data on the combination of polymorphic variants of estrogen receptor gene ESR1, allelic variant of the CYP $2 D 6$ gene, mutation of tumor suppressor gene BRCA1/2 in patients with $\mathrm{BC}$ and $\mathrm{OC}$.

\section{PATIENTS AND METHODS}

In the study, the clinical data on 210 women from the Cherkasy region (age, nationality, complaints, data of objective status after examination by an oncogynecologist and an oncology surgeon, results of mammographic examination, ultrasound of the pelvic organs and mammary glands, results of histological examination of tumors of the mammary gland and ovaries, scraps of the uterine mucosa), the data of the developed questionnaires for medical genetic counseling, pedigree, peripheral blood of patients with benign pathology and malignant pathology of $\mathrm{FRO}$ with a family history of cancer and women from the control group without complicated family oncoanamnesis, have been analyzed.

The study involved 65 patients with benign pathology of FRO (mammary gland, uterus, ovaries), 90 patients with cancer (BC, OC) from cancer-affected families, and 55 practically healthy women without cancer cases in pedigrees. All women surveyed were Ukrainians.

Among the total number of patients $(n=210$, $100 \%)$, the quantities of patients with benign pathology $(n=65,31.0 \%), B C(n=44,20.9 \%)$ and OC $(n=46,21.9 \%$ ) (in total, $90(42.8 \%)$ patients with cancer), and healthy women from the control group $(n=55,26.2 \%)$ were close enough (Table 1). The age of patients with benign pathology, cancer of the FRO from cancer-affected families, and healthy women from the control group fluctuated in the similar range - from 21 to 75 years (Table 2). The average age and median values for 10 years did not have a significant difference in the groups of women surveyed $(p>0.05)$.

The analysis of the reproductive-menstrual status of the examined women with benign pathology, patients with FRO cancer, and women from the control group is presented in Table 3.

Table 1. Distribution and characterization of FRO tumors in the examined patients ( $n=155$ ) with family history of cancer

\begin{tabular}{lclc}
\hline $\begin{array}{c}\text { Malignant } \\
\text { pathology }\end{array}$ & $\begin{array}{c}\text { Examined } \\
\text { patients } \\
(\mathrm{n}=90), \mathrm{n}(\%)\end{array}$ & Benign FRO pathology & $\begin{array}{c}\text { Examined } \\
\text { patients }^{*} \\
(\mathrm{n}=65), \mathrm{n}(\%)\end{array}$ \\
\hline OC & $46(51.1)$ & $\begin{array}{l}\text { Leiomyoma of the ute- } \\
\text { rus, uterine body ade- } \\
\text { nomyosis }\end{array}$ & $19(29.2)$ \\
BC & $44(48.9)$ & $\begin{array}{l}\text { Ovarian cyst } \\
\text { Fibroadenoma, cyst } \\
\text { of the mammary gland } \\
\text { *A combination of dif- } \\
\text { ferent forms of benign }\end{array}$ & $11(27.7)$ \\
& & $17(26.2)$ \\
$\begin{array}{l}\text { Total number } \\
\text { of examined } \\
\text { probands } \\
(\mathrm{n}=155)\end{array}$ & & \\
\hline
\end{tabular}

Table 2. Distribution of probands (patients with benign pathology and malignant tumors of FRO from cancer-affected families and healthy women without cases of cancer of the pedigree - control group) by average and median age

\begin{tabular}{|c|c|c|c|c|c|c|}
\hline \multirow{2}{*}{$\begin{array}{l}\text { Examined } \\
\text { patients }\end{array}$} & \multicolumn{6}{|c|}{ Age, years } \\
\hline & $21-30$ & $31-40$ & $41-50$ & $51-60$ & $61-70$ & $>70$ \\
\hline $\begin{array}{l}\text { Patients with } \\
\text { benign FRO }\end{array}$ & $19 / 29.2 \%$ & $15 / 23.1 \%$ & $18 / 27.7 \%$ & $8 / 12.3 \%$ & $5 / 7.7 \%$ & \\
\hline $\begin{array}{l}\text { pathology } \\
(\mathrm{n}=65 / 100 \%)\end{array}$ & & & & & & - \\
\hline Median age & 29.2 & 38.0 & 48.0 & 55.0 & 62.0 & \\
\hline verage age & 26.2 & 36.1 & 45.1 & 55.8 & 63.4 & \\
\hline $\begin{array}{l}\text { Patients with } \\
\text { FRO cancer } \\
\text { (n= } 90 / 100 \%)\end{array}$ & $5 / 5.6$ & $18 / 20.0$ & $31 / 34.4$ & $23 / 25.6$ & $9 / 10.0$ & $4 / 4.4$ \\
\hline Median age & 29.0 & 33.0 & 41.0 & 53.0 & 65.0 & 73.0 \\
\hline $\begin{array}{l}\text { Average age } \\
\text { Healthy wo- } \\
\text { men (control) } \\
(n=55 / 100 \%)\end{array}$ & $\begin{array}{c}28.6 \\
9 / 16.4 \%\end{array}$ & $\begin{array}{c}36.5 \\
27 / 49.0 \%\end{array}$ & $\begin{array}{c}46.5 \\
8 / 14.5 \%\end{array}$ & $\begin{array}{c}54.7 \\
9 / 16.4 \%\end{array}$ & $\begin{array}{c}64.0 \\
1 / 1.8 \%\end{array}$ & $\begin{array}{c}72.0 \\
1 / 1.8 \%\end{array}$ \\
\hline Median age & 29.0 & 39.0 & 48.0 & 52.0 & - & - \\
\hline $\begin{array}{l}\text { Average age } \\
\text { In total, } \\
210 \text { patients }\end{array}$ & $\begin{array}{c}27.7 \\
33\end{array}$ & $\begin{array}{c}35.6 \\
60\end{array}$ & $\begin{array}{c}46.6 \\
57\end{array}$ & $\begin{array}{c}56.0 \\
40\end{array}$ & 15 & 5 \\
\hline
\end{tabular}


Table 3. Distribution of cancer cases in families of probands with benign and malignant pathology of FRO (including tumors of probands)

\begin{tabular}{lcc} 
Malignant tumors & $\begin{array}{c}\text { Number of cancer } \\
\text { in families of probands } \\
\text { in benign FRO } \\
\text { inthology, } \mathrm{n} / \%\end{array}$ & $\begin{array}{c}\text { Number of cancer } \\
\text { cases in pedigree } \\
\text { in malignant FRO } \\
\text { pathology, } \mathrm{n} / \%\end{array}$ \\
\hline Cancer of the uterus body & $37 / 18.4$ & $68 / 21.2$ \\
OC & $38 / 18.9$ & $58 / 18.1$ \\
BC & $44 / 21.9$ & $74 / 23.0$ \\
Colon cancer & $72 / 35.8$ & $101 / 31.5$ \\
Gastric cancer & $10 / 5.0$ & $20 / 6.2$ \\
Total & $201 / 100$ & $321 / 100$ \\
\hline
\end{tabular}

In $37.8 \%$ of cancer patients, there were previous surgical treatments of benign processes in the mammary gland and ovaries, whereas in the control group there was no surgical interventions related to FRO. Similar tendency was observed in the group with benign pathology of FRO. Tumors in patients with benign pathology were significantly more often diagnosed during gynecological examination $(46.2 \%)$ than in cancer patients $(26.7 \%)$, in which the tumors were more often (in $28.9 \%$ of cases) found personally (in the case of the malignant pathology of the mammary gland). The highest number of benign and malignant neoplasms was diagnosed by the oncologist, oncogynecologist or oncology surgeon (50.7 and $44.4 \%$, respectively).

In all patients, the results of clinical, laboratory, instrumental research were analyzed, as well as clinical and genealogical data using a specially designed questionnaire, which was filled with proband independently, and then the results were analyzed and supplemented by consultation with a gynecologist-oncologist during a personal conversation with a proband and when reviewing medical documentation. after its comprehensive examination in accordance with the Ukrainian standards. During the conversation with the patients, we have established the number of relatives (with and without cancer pathology) and their degree of relationship to proband (proband - patients with benign or malignant tumors of the FRO and healthy women of the control group).

During the conversation with proband, the following data were documented: the number of relatives of the I-III degree of kinship with cancer, and their exact diagnosis ascertained, if possible, using medical records, the relation of cancer patient relatives to proband. Clinical and genealogical analysis and pedigree analysis were performed according to the Amsterdam criteria II (three or more relatives with Lynch-associated tumors - colorectal cancer, BC, cancer of uterus, ovary, gastric, and others, with one cancer patient having to have the I degree of kinship with other relatives, and malignant tumors - at least in two generations). In the examined healthy women (control group), there were no cancer history in relatives in the three generations. All patients with benign and malignant FRO tumors, which underwent clinical and genealogical examination, received medical assistance, including surgical, complex or combined treatment in accordance with its standards adopted in Ukraine, in Cherkasy Regional Oncology Dispensary (Cherkasy, Ukraine). All probandes provided informed written consent to the use of the data and biologic materials in scientific research.

The analysis of clinical-genealogical data in pedigrees of patients with benign pathology and cancer has revealed a wide range of tumor pathologies, among which predominated uterine cancer, OC, BC and colorectal cancer. The frequency of BC in benign/ malignant pathology in proband was $21.9 / 23.0 \%$, uterine cancer - 18.4/21.2\%, OC - 18.9/18.1\%, that is, the frequency of tumors of the hormone-dependent organs was quite large and amounted to 59.2/62.3\%, respectively. The data on cancer-affected relatives of probands with benign and malignant pathology of FRO are presented in Table 3.

According to the results of clinical and genealogical analysis of pedigrees, 65 patients with benign pathology of FRO (aged 23-64 years) in families with cancer history in 2-5 relatives of the I and II degree (Lynch II syndrome), proband relatives on the maternal line were more likely to suffer from cancer $(63 / 75.0 \%)$ than on parental line $(21 / 25.0 \%)$. In the analysis of pedigrees of 90 patients with malignant tumors of FRO (from 26 to 74 years old), an increase in the number of cancer cases in relatives on the maternal line compared with the parental line was noted both in patients with benign pathology of FRO (157/78.1\% and 44/21.9\%, respectively), and with malignant tumors $(282 / 87.9 \%$ and $39 / 12.1 \%$, respectively). Also, 55 women from the control group without the presence of cancer history in pedigree were examined (Table 4).

Table 4. Frequency of malignant tumors in patients with cancer of relatives of probands with benign FRO pathology

\begin{tabular}{|c|c|c|c|}
\hline \multicolumn{2}{|c|}{$\begin{array}{l}\text { Data on oncogenetic counseling } \\
\text { and clinical genealogical analysis } \\
\text { of pedigrees }\end{array}$} & $\begin{array}{c}\text { Benign } \\
\text { ( } n=65), \\
201 \text { cancer } \\
\text { patients } \\
\text { of probands } \\
\text { in pedigree, } \\
n(\%)\end{array}$ & $\begin{array}{c}\text { Malignant } \\
(n=90), \\
321 \text { cancer } \\
\text { patients } \\
\text { of probands } \\
\text { in pedigree, } \\
n(\%) \\
\end{array}$ \\
\hline I degree of kinship & Maternal line & $74(36.8)$ & $124(37.6)$ \\
\hline ( 2 relatives) & Paternal line & $19(9.5)$ & $15(4.7)$ \\
\hline II degree of kinship & Maternal line & $68(33.8)$ & $138(43.9)$ \\
\hline (2 relatives) & Paternal line & $19(9.5)$ & $14(4.5)$ \\
\hline I-II degree of kinship & Maternal line & $15(7.5)$ & $20(6.2)$ \\
\hline $\begin{array}{l}\text { ( } 3 \text { or more relatives of pa- } \\
\text { tients with cancer, up to } 6 \text { ) }\end{array}$ & Paternal line & $6(2.9)$ & $10(3.1)$ \\
\hline
\end{tabular}

The stage of the tumor process in cancer patients was evaluated according to the FIGO classification. Clinical diagnosis was verified by morphological examination of surgically removed tumors. The surgical material of the patients was subjected to classical histological analysis: staining of histological sections with hematoxylin and eosin and examination of slides using microscope "Axiostarplus" ("CarlZeiss") at magnification of 100-400. Histological peculiarities of malignant tumors and distribution of patients with $\mathrm{OC}$ and $\mathrm{BC}$ by the stages are presented in Table 5. 
Table 5. Morphological and clinical characteristics of patients with $\mathrm{BC}$ and $\mathrm{OC}$

\begin{tabular}{|c|c|c|c|c|c|c|c|c|}
\hline \multicolumn{2}{|c|}{$\begin{array}{c}\text { Distribution } \\
\text { of malignant tumors } \\
\text { by morphology }\end{array}$} & \multicolumn{2}{|c|}{$\begin{array}{l}\text { Serous } \\
\text { cancer }\end{array}$} & \multicolumn{2}{|c|}{$\begin{array}{l}\text { Adenocarci- } \\
\text { noma }\end{array}$} & \multicolumn{3}{|c|}{ Ductal cancer } \\
\hline \multirow{3}{*}{\multicolumn{2}{|c|}{$\begin{array}{l}\mathrm{OC}(\mathrm{n}=46 / 100 \%) \\
\mathrm{BC}(\mathrm{n}=44 / 100 \%) \\
\text { In total }(\mathrm{n}=90 / 100 \%)\end{array}$}} & \multirow{4}{*}{\multicolumn{2}{|c|}{$\begin{array}{c}32 / 69.6 \% \\
13 / 29.5 \% \\
45 / 50 \% \\
\text { OC }(46 / 100 \%)\end{array}$}} & \multirow{3}{*}{\multicolumn{2}{|c|}{$\begin{array}{l}14 / 30.4 \% \\
12 / 27.3 \% \\
26 / 28.9 \%\end{array}$}} & \multirow{3}{*}{\multicolumn{3}{|c|}{$\begin{array}{l}- \\
/ 43.2 \% \\
/ 21.1 \%\end{array}$}} \\
\hline & & & & & & & & \\
\hline & & & & & & & & \\
\hline Distribution & & & & & & $(44 / 1$ & & \\
\hline & I & $\|$ & III & IV & 1 & $\|$ & III & \\
\hline RO & 10 & 3 & 26 & 7 & 15 & 29 & - & 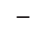 \\
\hline y stages & $21.7 \%$ & $6.5 \%$ & $56.6 \%$ & $15.2 \%$ & $34.1 \%$ & $65.9 \%$ & - & - \\
\hline
\end{tabular}

As it is shown in the Table 5, malignant tumors of serous type were found more often in both $\mathrm{OC}$ $(69.6 \%)$ and BC (29.5\%), the most commonly of high differentiation grade in both cases (G1 (47.8\%)). In stages among patients with malignant tumors of the OBR, The patients with OC were more often diagnosed with stage III of the disease (56.6\%), and with BC in stage II (65.9\%).

Molecular genetic studies of peripheral blood were carried out as follows: DNA extraction from peripheral blood leukocytes, amplification of the studied DNA fragments, electrophoretic distribution of amplification fragments, or analysis of restriction fragments in an agarose gel. Firstly, the total or total genomic DNA was collected from peripheral blood leukocytes from $100 \mu \mathrm{l}$ blood. For this purpose, a standard commercial kit with sorbent was used, the principle of which is that after the previous lysis of blood cells, released DNA is fixed on the sorbent. This facilitates the process of isolation and reduces its loss during further purification. After fixing onto the sorbent, DNA was washed with special solutions to obtain purified DNA with minimal impurities. Secondly, the number of copies of the studied gene fragments was increased in order to allow further identification of the deletion variant or single-nucleotide replacement. Polymerase chain reaction (PCR) was used to multiply the number of copies of the fragment of the DNA under study. When conducting PCR, the synthesis of complementary chains of the investigated DNA fragment in artificial conditions is achieved, which is achieved due to optimal temperature conditions and due to the optimal ratio of reagents in the test tube.

Multiplex PCR (amplification) was used to study three mutations in BRCA1 (1185delAG, 5382insC) and BRCA2 (6174delT) genes in DNA samples from peripheral blood. The resulting amplicons had different molecular weights, so they can be separated by the method of horizontal agarose gel electrophoresis. After standart PCR of DNA fragment of ESR 1 gene (A-351G, T-397C) and CYP 2D6*4 gene (G1846A) was performed a restriction analysis of PCR products, and the fragments were analyzed also by comparison of restriction fragments in $1.5 \%$ agarose gel by horizontal electrophoresis.

For molecular genetic studies to detect 185delAG and 5382insC mutations in BRCA1 gene, 6174delT mutation in BRCA1 gene, mutations $6174 \mathrm{delTu}$ in BRCA2 gene and polymorphic variants of ESR gene (A-351G, T-397C) and CYP 2D6*4 gene (G1846A), genomic DNA was also isolated from the histological sections of the paraffin blocks of the operation material from 46 patients with BC (23/50\%) and OC (23/50\%). The material was delivered in microtubes to the laboratory of the State Institution "Reference Center for Molecular Diagnostics of the Ministry of Health of Ukraine". For deparaffinization to paraffin sections, $750 \mu$ of $100 \%$ xylene were added, vortexed for $15 \mathrm{~s}$, and incubated at room temperature not less than $1 \mathrm{~h}$. The samples were centrifuged for $1 \mathrm{~min}$ at $12,000 \mathrm{~g}$, supernatant was removed. The deparaffinization procedure was repeated again in the same way. To remove the xylene residues after de-paraffinization, the samples were washed in four steps according to the standard procedure [23].

To detect mutations in the genes and the presence of 185 delAG and 5382insC mutations in the BRCA1 gene, mutations in 6174delTu in BRCA2 gene, and polymorphisms in ESR1 (A-351G, T-397C) and CYP 2D6*4 (G1846A) genes, the study was performed on peripheral blood samples of patients with family history of cancer, namely: 44 patients with $\mathrm{BC}$ $(n=21)$ and $O C(n=23)$, and 65 women with benign neoplasms of FRO with family history of cancer. Also, molecular genetic studies of peripheral blood were conducted for the presence of the same polymorphisms in 55 practically healthy women from the control group, without known hereditary risk factors for malignant pathology.

The peripheral blood was collected in sterile tubes of the system "Monovet" in volume of $2.5 \mathrm{ml}$ with ethylenediaminetetraacetic acid (EDTA) manufactured by the company "Sarstedt". Sterile tubes with the obtained material were stored at $-20{ }^{\circ} \mathrm{C}$ (no more than 1 month) in freezers until they were transported to the molecular genetic laboratory of the Reference Center for Molecular Diagnostics of the Ministry of Health of Ukraine. Transportation of th samples was carried out in frozen state in cold containers. For the extraction of DNA from peripheral blood, the commercial kit "DNA-Sorb-B" was used according to the instructions of the manufacturer. Determination of the polymorphism of the genes studied was carried out using a PCR with ThermoScientific reagents, using a standard protocol [24] and specific primers.

Statistical processing was performed using programs MSExcel 2010 and Statistica 10. To analyze the differences in the obtained numerical indices, the methods of variation statistics were used, the genotype frequencies - Pearson's criterion $\chi^{2}$, if a sample size of less than 10 - the Yates correction was used, and odds ratio (OR) was calculated with a confidence interval (95\% confidence interval - Cl).

To assess the role of intergene interaction in the development of benign and malignant pathologies in the examined women and the creation of genetic 
risk models, the Multifactor Dimensionality Reduction (MDR 2.0) using the appropriate software: MDR (version 2.0., http://www.epistasis.org/mdr.html) was used [25].

Using this method, we conducted a statistical evaluation of the reproducibility of the tested models. In the MDR program, multiloci genotypes are summarized in groups of increased and reduced risk of developing the disease. With the help of multiple cross-recounting of the initial data entered, the optimal model of intergene interactions is selected, which allows with the highest accuracy and, accordingly, with the slightest error, to predict the presence or absence of a predisposition to the development of benign or malignant tumors (pathological states). The mathematical basis of this program is a nonparametric cluster analysis, which serves as an alternative to logistic regression to identify and describe the nonlinear type of interaction between discrete genetic markers. In the process of modeling, we used highly conservative configuration settings for model search, which allowed us to uniquely differentiate the presence/absence of statistically significant effects: the number of attributes (attribute count range) - from 1 to $n$ (where $n-$ the number of genes in the model); reproducibility of the model (cross-validation count) -10 . We have calculated $\chi^{2}$, the relative risk index OR at $95 \% \mathrm{Cl}$, the differences were considered to be significant at $p<0.05$.

\section{RESULTS AND DISCUSSION}

The analysis of the frequencies of the genotypes of the investigated genes was carried out differentially - depending on the number of patients with benign or malignant pathology in the families. The control group involved practically healthy women from cancer-uncomplicated pedigree.

The results of the statistical analysis (Table 6) of the genotype frequencies for polymorphic variants of ESR1 gene (T397C) showed that in patients with benign pathology of $\mathrm{FRO}$, a significant increase in the frequency of the 397CC genotype was found in the case of aggregation of malignant pathology in pedigrees compared with the frequency of this genotype in women of the comparison group (without cancer-burdened anamnesis (OR $=5.20,95 \%$ Cl 1.42-19.06, $p=0.015)$ ). In the presence of 397TC genotype of ESR1 gene, the risk of developing benign pathology is significantly lower $(\mathrm{OR}=2.55$, $95 \% \mathrm{Cl} 1.21-5.38, p=0.021$ ). For 397TT genotype, a protective effect (a decrease in the risk of developing pathology) was established (OR $=0.17,95 \%$ $\mathrm{Cl} 0.08-0.38, p=0.001$ ). Among the patients with benign tumors, the frequency of genotypes 397CC + $397 C T(\mathrm{OR}=5.90,95 \% \mathrm{Cl} 2.64-13.17, p=0.001)$ prevalents with high reliability, that is, the presence of this polymorphic variant in the homo- or heterozygous state increases the risk of development of benign tumors by 5.9 times.
Table 6. Distribution of polymorphic variants of ESR1 (T-397C, A-351G) and CYP 2D6*4 (G1846A) genes in patients with benign FRO pathology and healthy women (control group)

\begin{tabular}{|c|c|c|c|c|c|c|c|c|}
\hline \multirow[t]{2}{*}{ Genotypes } & \multicolumn{2}{|c|}{$\begin{array}{c}\text { Benign } \\
\text { pathology } \\
(\mathrm{n}=65)\end{array}$} & \multicolumn{2}{|c|}{$\begin{array}{l}\text { Control } \\
\text { group } \\
(\mathrm{n}=55)\end{array}$} & \multicolumn{4}{|c|}{ Results of statistical analysis } \\
\hline & $\mathrm{n}$ & $\%$ & $\mathrm{n}$ & $\%$ & $\overline{\chi^{2}}$ & $p$ & $\overline{\mathrm{OR}}$ & $95 \% \mathrm{Cl}$ \\
\hline \multicolumn{9}{|c|}{ ESR1 (T397C) gene } \\
\hline TT & 14 & 21.54 & 34 & 61.82 & 18.5 & 0.001 & 0.17 & $0.08-0.38$ \\
\hline TC & 36 & 55.38 & 18 & 32.73 & 5.3 & 0.021 & 2.55 & $1.21-5.38$ \\
\hline CC & 15 & 23.08 & 3 & 5.45 & 5.94 & 0.015 & 5.20 & $1.42-19.06$ \\
\hline $\mathrm{TC}+\mathrm{CC}$ & 51 & 78.46 & 21 & 38.18 & 8.50 & 0.001 & 5.90 & $2.64-13.17$ \\
\hline \multicolumn{9}{|c|}{ ESR1 (A351G) gene } \\
\hline AA & 23 & 35.38 & 37 & 67.27 & 10.88 & 0.001 & 0.27 & $0.12-0.57$ \\
\hline AG & 32 & 49.23 & 18 & 32.73 & 2.69 & 0.101 & 1.99 & $0.95-4.19$ \\
\hline GG & 10 & 15.38 & 0 & 0.00 & 7.33 & 0.007 & - & - \\
\hline$A G+G G$ & 42 & 64.62 & 18 & 32.73 & 10.88 & 0.001 & 3.75 & $1.76-8.02$ \\
\hline \multicolumn{9}{|c|}{ CYP 2D6*4 (G1846A) gene } \\
\hline GG & 42 & 64.62 & 45 & 81.82 & 4.42 & 0.035 & 0.41 & $0.17-0.95$ \\
\hline GA & 17 & 26.15 & 10 & 18.18 & 0.68 & 0.411 & 1.59 & $0.66-3.84$ \\
\hline & 6 & 9.23 & 0 & 0.00 & 3.58 & 0.059 & - & - \\
\hline $\mathrm{GA}+\mathrm{AA}$ & 23 & 35.38 & 10 & 18.18 & 4.53 & 0.032 & 2.34 & $1.05-5.14$ \\
\hline
\end{tabular}

According to our data, the genotypes $A A$ and GG of ESR1 gene have a protective effect, and for $A G$ genotype of this gene the data were insignificant $(p>0.05)$.

The risk of development of benign pathology in the presence of an unfavorable polymorphic variant $1846 G A$ or $1846 A A$ of $C Y P 2 D 6 * 4$ gene in the homo- or heterozygous state increases by 2.34 times ( $p=0.032,95 \% \mathrm{Cl} 1.05-5.14)$, whereas in the presence of the $1846 \mathrm{GG}$ genotype of this gene, the risk of developing the disease is reduced ( $O R=0.41$, $95 \% \mathrm{Cl} 0.17-0.95, p=0.035)$. Thus, there is a different risk of benign pathology in women with canceraffected families burdened with malignant pathology: a significant increase by 2.34 times (genotype $G A+$ $A A$ of $C Y P 2 D 6^{\star} 4$ gene), 3.75 times ( $A G+G G$ genotype of ESR1 gene) and 2.55-5.90 times (genotypes TC, $C C, T C+C C$ of ESR1 gene).

Distribution of polymorphic variants of these genes in cancer patients with family history of cancer is presented in Table 7.

In patients with FRO cancer, there was registered a typical increase in the frequency of 397Ts and $397 S S$ genotypes of ESR1 (T397C) gene, as compared to controls $(\mathrm{OR}=2.25,95 \% \mathrm{Cl} 1.12-4.52, p=$ 0.034 , and $\mathrm{OR}=4.95,95 \% \mathrm{Cl} 1.40-17.55, p=0.014$, respectively). The genotype $397 T T$ had a protective effect regarding the development of oncopathology (OR $=0.21,95 \% \mathrm{Cl} 0.10-0.44, p=0.001)$. As can be seen from Table 2, in the presence of a polymorphic variant of $397 C C$ or $397 C T$ in homo- or heterozygous state, the risk of developing cancer is increased by 4 -fold.

In patients with FRO cancer there was found just a tendency to increased frequency of 351 GG genotype in ESR1 gene $(p>0.05)$. Significant differences were found for 351AG genotype of ESR1 gene (OR $=2.81,95 \% \mathrm{Cl} 1.39-5.67, p=0.006$ ), while for $351 \mathrm{AA}$ genotype - a protective effect $(\mathrm{OR}=0,2495 \%$ $\mathrm{Cl} 0.12-0.50, p=0.006)$. In these patients a significant increase in the frequency of $1846 \mathrm{GA}$ and $1846 \mathrm{AA}$ genotypes of $C Y P 2 D 6^{\star} 4$ gene was observed, on the basis of which it can be stated that the risk of developing 
cancer in the presence of an unfavorable polymorphic variant in homo- or heterozygous state increases by 2.25 times.

Table 7. Distribution of polymorphic variants of ESR1 (A-351G, T-397C), CYP $2 D 6^{*} 4$ (G1846A) and BRCA1/2 genes in cancer patients with $O C$ with a burden of the oncological pathology in the families and in the women from the control group

\begin{tabular}{|c|c|c|c|c|c|c|c|c|}
\hline \multirow[t]{2}{*}{ Genotypes } & \multicolumn{2}{|c|}{$\begin{array}{c}\text { Malignant } \\
\text { pathology } \\
(\mathrm{n}=90)\end{array}$} & \multicolumn{2}{|c|}{$\begin{array}{c}\text { Control } \\
\text { group } \\
(\mathrm{n}=55) \\
\end{array}$} & \multicolumn{4}{|c|}{ Results of statistical analysis } \\
\hline & $\mathrm{n}$ & $\%$ & $\mathrm{n}$ & $\%$ & $x^{2}$ & $p$ & OR & $95 \% \mathrm{Cl}$ \\
\hline \multicolumn{9}{|c|}{ ESR1 (T397C) gene } \\
\hline TT & 23 & 25.56 & 34 & 61.82 & 17.33 & 0.001 & 0.21 & $0.10-0.44$ \\
\hline TC & 47 & 52.22 & 18 & 32.73 & 4.49 & 0.034 & 2.25 & $1.12-4.52$ \\
\hline $\mathrm{CC}$ & 20 & 22.22 & 3 & 5.45 & 5.99 & 0.014 & 4.95 & $1.40-17.55$ \\
\hline $\mathrm{TC}+\mathrm{CC}$ & 67 & 74.44 & 21 & 38.18 & 17.33 & 0.001 & 4.72 & $2.29-9.70$ \\
\hline \multicolumn{9}{|c|}{ ESR1 (A351G) gene } \\
\hline AA & 30 & 33.33 & 37 & 67.27 & 14.48 & 0.001 & 0.24 & $0.12-0.50$ \\
\hline AG & 52 & 57.78 & 18 & 32.73 & 7.61 & 0.006 & 2.81 & $1.39-5.67$ \\
\hline & 8 & 8.89 & 0 & 0.00 & 3.61 & 0.057 & - & - \\
\hline$A G+G G$ & 60 & 66.67 & 18 & 32.73 & 14.48 & 0.001 & 4.11 & $2.01-8.39$ \\
\hline \multicolumn{9}{|c|}{ CYP 2D6*4 (G1846A) gene } \\
\hline GG & 60 & 66.67 & 45 & 81.82 & 3.2 & 0.074 & 0.44 & $0.20-1.00$ \\
\hline GA & 28 & 31.11 & 10 & 18.18 & 2.32 & 0.128 & 2.03 & $0.90-4.60$ \\
\hline AA & 2 & 2.22 & 1 & 0.00 & 0.14 & 0.704 & - & - \\
\hline $\mathrm{GA}+\mathrm{AA}$ & 30 & 33.33 & 10 & 18.18 & 3.92 & 0.047 & 2.25 & $1.00-5.07$ \\
\hline \multicolumn{9}{|c|}{ BRCA1 (5382insC) gene } \\
\hline NN & 80 & 88.89 & 55 & 100.00 & 405 & 0.026 & - & - \\
\hline NM & 10 & 11.11 & 0 & 0.00 & 4.95 & - & - & - \\
\hline MM & 0 & 0.00 & & 0.00 & - & - & - & - \\
\hline \multicolumn{9}{|c|}{ BRCA2 (6174delT) gene } \\
\hline NN & 86 & 95.56 & 55 & 100.00 & 113 & 0.288 & - & - \\
\hline NM & 4 & 4.44 & 0 & 0.00 & 1.13 & - & - & - \\
\hline MM & 0 & 0.00 & 0 & 0.00 & - & - & - & - \\
\hline
\end{tabular}

In general, in cancer patients compared with patients without family history of cancer, 5382insC mutation in the BRCA1 gene in the heterozygous state $\left(X^{2}=4.95, p=0.026\right)$ was detected at significant rate; in 4 cases $6174 d e / T$ mutations in the $B R C A 2$ gene in the heterozygous state were detected (see Table 2).

To evaluate the complex contribution of the genetic component to the development of cancer pathology, we conducted an analysis of all possible combinations of polymorphic variants of the investigated genes in the groups of examined patients (Table 8).

Table 8. Combinations of genotypes of the studied ESR1 (T397C/A351G), CYP 2D6*4 (G1846A) and BRCA1 (5382insC) genes associated with an increased risk of benign FRO pathology

\begin{tabular}{|c|c|c|c|c|c|c|c|c|}
\hline \multirow[t]{2}{*}{$\begin{array}{l}\text { Combination } \\
\text { of genotypes }\end{array}$} & \multicolumn{2}{|c|}{$\begin{array}{c}\text { Benign } \\
\text { pathology } \\
(\mathrm{n}=65)\end{array}$} & \multicolumn{2}{|c|}{$\begin{array}{c}\text { Control } \\
\text { group } \\
(\mathrm{n}=55)\end{array}$} & \multicolumn{4}{|c|}{ Results of statistical analysis } \\
\hline & $n$ & $\%$ & $\mathrm{n}$ & $\%$ & $x^{2}$ & OR & $p$ & $95 \% \mathrm{Cl}$ \\
\hline \multicolumn{9}{|c|}{ ESR1 (T397C/A351G) } \\
\hline TT/AA & 13 & 20.97 & 32 & 58.18 & 16.94 & 0.18 & 0.001 & $0.08-0.40$ \\
\hline $\mathrm{C} / \mathrm{AC}$ & 27 & 41.54 & 13 & 23.64 & 4.29 & 2.30 & 0.038 & $4-5.08$ \\
\hline $\mathrm{CC} / \mathrm{G}$ & 10 & 15.38 & 0 & 0.00 & 7.33 & - & 0.007 & - \\
\hline \multicolumn{9}{|c|}{ ESR1 (T397C)/CYF } \\
\hline $\mathrm{TT} / \mathrm{GG}$ & 8 & 12.31 & 25 & 45.45 & 14.80 & 0.17 & 0.001 & $0.07-0.42$ \\
\hline $\mathrm{CC} / \mathrm{C}$ & 6 & 9.23 & 0 & 0.00 & 5.34 & - & 0.021 & - \\
\hline \multicolumn{9}{|c|}{ ESR1 (A351G)/CYP } \\
\hline $\mathrm{AA} / \mathrm{GG}$ & 15 & 23.08 & 27 & 49.09 & 7.76 & 0.31 & 0.005 & $0.14-0.68$ \\
\hline$G / G$ & 7 & 10.77 & 0 & 0.00 & 6.28 & - & 0.012 & - \\
\hline $\mathrm{GG} / \mathrm{G}$ & 5 & 7.69 & 0 & 0.00 & 4.41 & - & 0.035 & - \\
\hline \multicolumn{9}{|c|}{ T397C/A351G/G1846A } \\
\hline $\mathrm{TT} / \mathrm{A}$ & 0 & 12.31 & 23 & 41.82 & 13.54 & 0.20 & 0.001 & $0.08-0.49$ \\
\hline TT/AA & 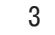 & 4.61 & 9 & 16.36 & 4.08 & 0.22 & 0.049 & $0.06-0.86$ \\
\hline $\mathrm{TC} / \mathrm{AC}$ & 5 & 7.69 & 0 & 0.00 & 4.41 & - & 0.035 & - \\
\hline $\mathrm{CC} / \mathrm{C}$ & 5 & 7.69 & 0 & 0.00 & 4.41 & - & 0.035 & - \\
\hline \multicolumn{9}{|c|}{ BRCA1 (5382insC)/T397C/A351G/CYP 2D6*4 } \\
\hline $\mathrm{NM} / \mathrm{C}$ & 1 & 1.54 & 0 & 0.00 & 0.85 & - & 0.356 & - \\
\hline & 1 & 1. & 0 & 0.0 & 0.85 & - & 0.356 & - \\
\hline $\mathrm{VM} / \mathrm{CC} / \mathrm{C}$ & 1 & 1.54 & 0 & 0.00 & 0.85 & - & 0.356 & 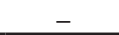 \\
\hline
\end{tabular}

Subsequently, using bioinformatics method of MDR 2.0, we evaluated the role of the combination of genes and intergene interactions to form a model of intergene interaction in the development of benign tumor pathology in the examined women (Table 9).

Table 9. Established models of intergene interaction in the development of benign pathology using the MDR 2.0 program in comprehensive search mode

\begin{tabular}{clcc}
\hline $\begin{array}{c}\text { Number } \\
\text { of genes in model }\end{array}$ & $\begin{array}{c}\text { Combinations of genes } \\
\text { in prognostic model }\end{array}$ & $\begin{array}{c}\text { Reproduci- } \\
\text { bility of the } \\
\text { model }\end{array}$ & $\begin{array}{c}\text { Accuracy } \\
\text { of the } \\
\text { model, } \%\end{array}$ \\
\hline $1^{*}$ & T397C & $10 / 10$ & 70.14 \\
$2^{* *}$ & T397C/CYP 2D6*4 & $10 / 10$ & 71.68 \\
$3^{*}$ & T397C/A351G/CYP 2D6*4 & $10 / 10$ & 67.20 \\
$4^{*}$ & insC/T397C/A351G/ & $10 / 10$ & 69.79 \\
& CYP 2D6*4 & & \\
\hline
\end{tabular}

Notes: ${ }^{*}$ The best model $(p \leqslant 0,01)$ among the $n$-gene models is determined.

${ }^{* *}$ The best model $(p \leqslant 0,001)$ among the $n$-gene models is determined.

The best prognostic model with high accuracy $(71.68 \%)$ to predict benign pathology in women with family history of cancer is a model with two genes ESR1 (T397C) and CYP 2D6*4 (G1846A) which can be used for the study of gene polymorphism. Using graphic imaging, we determined the contribution of each polymorphism to the risk of developing a pathology (Fig. 1, 2). The high entropy index (13.59\%) was determined for the estrogen receptor gene ESR1 (T397C), which, according to the image, has a negative relationship with other genes (blue and green), i.e. has a predominantly isolated effect on the increase of the risk of the disease. Based on the analysis of all four indeces, we can conclude on the leading role of the T397C polymorphism in ESR1 gene among all the analyzed genes.

In cancer patients and women of the control group, an assessment of genotypes combinations of the investigated genes was performed (Table 10).

Table 10. Combinations of genotypes of the investigated genes ESR1 (T397C/A351G), CYP 2D6*4 (G1846A) and BRCA1 (5382insC), $B R C A 2$ (6174delT) associated with an increased risk of malignant pathology

\begin{tabular}{|c|c|c|c|c|c|c|c|c|}
\hline \multirow[t]{2}{*}{$\begin{array}{l}\text { Combinations } \\
\text { of genotypes }\end{array}$} & \multicolumn{2}{|c|}{$\begin{array}{c}\text { Malignant } \\
\text { pathology } \\
(\mathrm{n}=90)\end{array}$} & \multicolumn{2}{|c|}{$\begin{array}{c}\text { Control } \\
\text { group } \\
(n=55)\end{array}$} & \multicolumn{4}{|c|}{$\begin{array}{c}\text { Results } \\
\text { of statistical analysis }\end{array}$} \\
\hline & $\mathrm{n}$ & $\%$ & $\mathrm{n}$ & $\%$ & $x^{2}$ & OR & $p$ & $95 \% \mathrm{Cl}$ \\
\hline \multicolumn{9}{|c|}{$\operatorname{ESR1}(T 397 C / A 351 G)$} \\
\hline TT/AA & 21 & 23.33 & 32 & 58.18 & 12.63 & 0.26 & 0.001 & $0.12-0.53$ \\
\hline $\mathrm{TC} / \mathrm{AG}$ & 38 & 42.22 & 13 & 23.64 & 4.39 & 2.36 & 0.036 & $1.12-5.00$ \\
\hline $\mathrm{CC} / \mathrm{GG}$ & 8 & 12.31 & 0 & 0.00 & 5.17 & - & 0.047 & - \\
\hline \multicolumn{9}{|c|}{ ESR1 $(T 397 C) / C Y P 2 D 6^{\star} 4(G 1846 A)$} \\
\hline TT/GG & 17 & 18.89 & 25 & 45.45 & 10.45 & 0.28 & 0.001 & $0.13-0.59$ \\
\hline $\mathrm{TC} / \mathrm{GA}$ & 16 & 17.78 & 1 & 1.82 & 6.93 & 11.68 & 0.008 & $1.50-80.74$ \\
\hline \multicolumn{9}{|c|}{ ESR1 (A351G)/CYP 2D6*4 (G1846A) } \\
\hline $\mathrm{AA} / \mathrm{GG}$ & 19 & 21.11 & 27 & 49.09 & 12.33 & 0.28 & 0.001 & $0.13-0.58$ \\
\hline $\mathrm{AG} / \mathrm{GA}$ & 14 & 15.56 & 0 & 0 & 9.46 & - & 0.013 & - \\
\hline \multicolumn{9}{|c|}{ T397C/A351G/G1846A } \\
\hline TT/AA/GG & 15 & 16.66 & 23 & 41.82 & 9.9 & 0.28 & 0.002 & $0.13-0.60$ \\
\hline $\mathrm{TC} / \mathrm{AG} / \mathrm{GA}$ & 11 & 12.22 & 0 & 0 & 7.27 & - & 0.018 & - \\
\hline \multicolumn{9}{|c|}{ BRCA2 (6174delT)/T397C/A351G/CYP 2D6*4 (G1846A) } \\
\hline $\mathrm{NM} / \mathrm{TC} / \mathrm{AG} / \mathrm{GA}$ & 1 & 1.11 & 0 & 0.00 & 0.06 & - & 0.803 & - \\
\hline NM/TC/AA/GG & 1 & 1.11 & 0 & 0.00 & 0.06 & - & 0.803 & - \\
\hline $\mathrm{NM} / \mathrm{CC} / \mathrm{AG} / \mathrm{GG}$ & 2 & 2.22 & 0 & 0.00 & 0.14 & - & 0.704 & - \\
\hline \multicolumn{9}{|c|}{ BRCA1 (5382insC)/T397C/A351G/CYP 2D6*4 (G1846A) } \\
\hline $\mathrm{NM} / \mathrm{TT} / \mathrm{AA} / \mathrm{GA}$ & 1 & 1.11 & 0 & 0.00 & 0.06 & - & 0.803 & - \\
\hline NM/TC/AA/GA & 1 & 1.11 & 0 & 0.00 & 0.06 & - & 0.803 & - \\
\hline $\mathrm{NM} / \mathrm{TC} / \mathrm{AG} / \mathrm{GG}$ & 3 & 3.33 & 0 & 0.00 & 0.59 & - & 0.443 & - \\
\hline $\mathrm{NM} / \mathrm{TC} / \mathrm{AG} / \mathrm{GA}$ & 4 & 4.44 & 0 & 0.00 & 1.13 & - & 0.288 & - \\
\hline
\end{tabular}

As can be seen from Table 5, we have identified protective combination of genotypes and combina- 


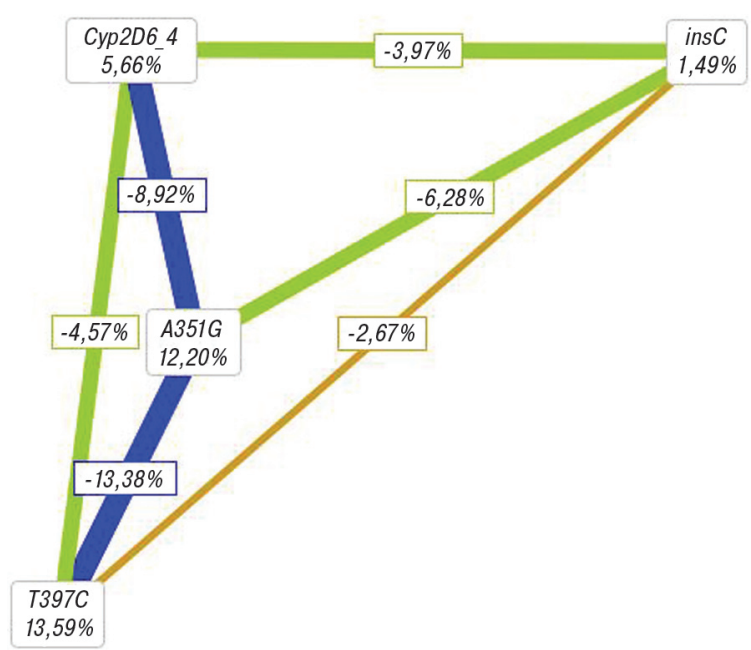

Fig. 1. Graphical representation of the results of the analysis of interactions between the investigated genes in women with benign pathology

Note: green, blue - antagonistic interaction between the gene loci, brown color - the independent effect of individual loci on the risk of the disease. The lines between the genes on Fig. 1 shows the type and degree of interaction. The long lines in the dendrogram describe a weak link between the genes, short lines - stronger interaction, the color characterises the type of interaction: blue - the independent effect, green - the enhancing effect of the gene. On the apexes of the polyhedron is the informative value of each gene, on the edges - the informative value of the interaction of a pair of genes. Since the nature of the interaction of the investigated genes in the model had an independent effect, the interaction between the genes is negative.

tions of genotypes associated with an increased risk of FRO. Among the women from the control group, the combination of $T T / A A, T T / G G, A A / G G$, $T T / A A / G G$ was significantly predominant compared to $E S R 1$ and $C Y P 2 D 6^{\star} 4$ genes. The frequency of genotypes TC/AG, TC/GA, AG/GA, TC/AG/GA of ESR1 and $C Y P 2 D 6^{\star} 4$ genes was higher in the cancer patients group. In the control group CC/GG, AG/GA, TC/AG/ $G A$ combinations were not find at all, therefore, the OR was not calculated for this group, but their similar prevalence among patients points to their importance in relation to increased risk of pathology.

Mutations in high-penetrant BRCA1 and $B R C A 2$ genes (see Table 5) were also found in combination with other investigated genotypes of ESR1 (A351G, T397C) and CYP 2D6*4 (G1846A) genes. In 9 out of 10 cases, we found a combination of $B R C A 1$ (5382insC) with genotypes of the investigated genes that increase the risk of oncological pathology, and in 4 of the 4 cases, the BRCA2 genotype (6174de/T) was associated with the genotype of the high risk of oncological pathology, indicating a modifying effect these genotypes in the presence of highpenetrant mutations. A similar modifying effect was observed in patients with benign pathology in whom $B R C A 1$ (5382insC) genotype was combined with the risk genotypes of the investigated genes.

In the modeling of intergene interaction in cancer patients and in control group, the one-locus model that included the ESR1 gene (T397C) with an accuracy

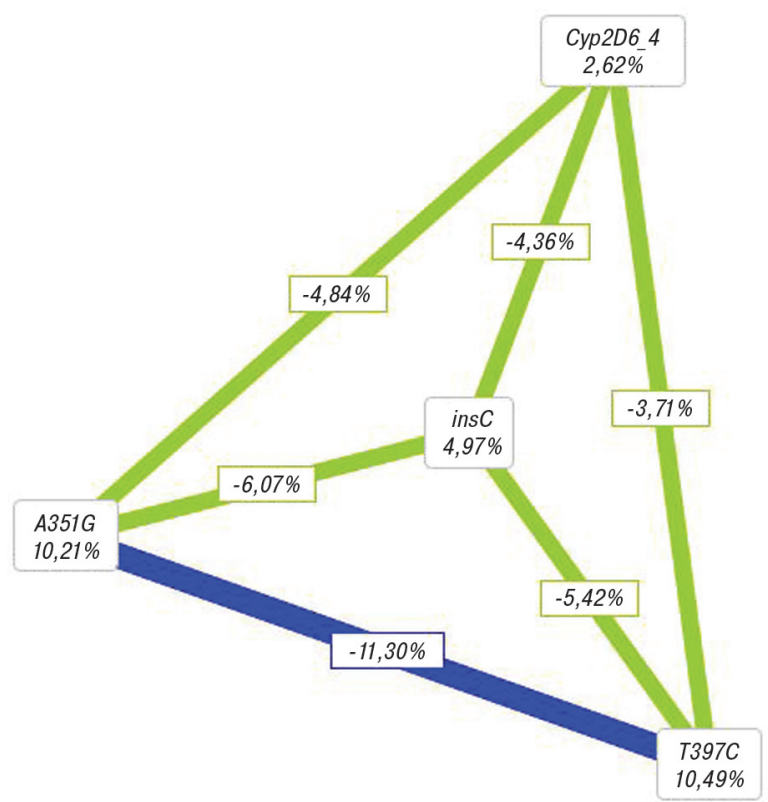

Fig. 2. Graphical representation of the results of the analysis of interactions between the investigated genes in cancer patients Note: green, blue colors - antagonistic interaction between the loci, other marks - see Fig. 1.

of $68.23 \%$ with a reproducibility of $90 \%$ was found to be the best model for prediction (Table 11).

To predict malignant pathology, the study of ESR1 (T397C) gene polymorphism should be conducted, which had the highest degree of entropy $10.49 \%$, and an independent negative relation with other genes (entropy - degree of uncertainty).

Thus, as can be seen from the data presented, the patients and families with a family history of oncological pathologies should first undergo an analysis of ESR1 gene polymorphism (T397C) for treatment planning and an indication of preventive measures. If we analyze the data in general, we can conclude that in the era of personalized medicine and personalized oncology, in particular, the key direction is the identification of individual risk factors of the disease and conditions that may be associated with them and manifest in the early stages of tumor growth $[18,19]$. Such a provision dictates the development of genetic programs for the prevention and early diagnosis of neoplasia, which will promote not only the discovery of genetic and molecular genetic signs of tumor growth, but also the ability to distribute tumors according to the heterogeneity of such changes. The latter is also important for targeted molecular therapy and

Table 11. Models of intergene interaction in the development of malignant pathology of FRO defined using the MDR 2.0 program in comprehensive search mode

\begin{tabular}{clcc}
\hline $\begin{array}{c}\text { The number } \\
\text { of genes in the } \\
\text { model }\end{array}$ & $\begin{array}{c}\text { Combinations of genes } \\
\text { in the prognostic model }\end{array}$ & $\begin{array}{c}\text { Reproduc- } \\
\text { ibility of the } \\
\text { model }\end{array}$ & $\begin{array}{c}\text { Accuracy } \\
\text { of the } \\
\text { model, \% }\end{array}$ \\
\hline $1^{*}$ & T397C & $9 / 10$ & 68.23 \\
$2^{*}$ & insC/T397C & $8 / 10$ & 66.11 \\
$3^{*}$ & T397C/A351G/CYP 2D6*4 & $7 / 10$ & 65.56 \\
$4^{*}$ & $\begin{array}{l}\text { insC/T397C/A351G/ } \\
\text { CYP 2D6*4 }\end{array}$ & $7 / 10$ & 65.00 \\
\hline
\end{tabular}

Note: ${ }^{\star}$ The best model $(p \leqslant 0.05)$ among $\mathrm{n}$-gene models is determined. 
the development of new approaches to the prevention and treatment of FRO cancer [26, 27].

Molecular changes in non-malignant cells, including mutations and polymorphisms of genes, in the absence of breast or ovarian pathology in women from cancer-affected families, are reliable indicators of genetic instability of somatic or germ cells, which is of fundamental importance for the study of the tendency of an organism to develop tumors. A positive example of this trend in modern research, in particular early screening of OC, is a program PROMISE 2016 (Predicting Risk of Ovarian Malignancies, Improved Screening and Early Detection), which takes into account not only clinical data on the patients, but also the proteomic and genetic characteristics of cells and high-penetrant genes (BRCA1/2) and a number of other genes (BRIP1, RAD51C and RAD51D) [17].

The importance of further studying genetic changes in cells is important for the genetic testing of women from families with history of cancer. According to the literature, genetic changes in tumor cells are predictive factors for the sensitivity to platinum preparations and are associated with tumor chemoresistance as a result of mutations associated with tumor progression, as well as survival of patients with $\mathrm{OC}, \mathrm{BC}$, and fallopian tubes [28-30]. In our opinion, although the mutations and single nucleotide polymorphisms (SNPs) reliably reflect the molecular changes of the already developed tumors, knowledge of the individual characteristics of tumor growth, that is, its personal phenotype, requires knowledge of its morphological, proteomic and metabolic characterization, which will make it possible to detail the changes in tumor cells in general and more correctly establish the prognosis of the tumor process. In addition, the emergence of the possibility of determining the molecular changes in nonmalignant cells of patients with cancer-affected families improves the effectiveness of medico-genetic counseling via a comprehensive examination of patients for the diagnosis of tumor growth in the early stages or at the stage of its preclinical manifestations, followed by the appropriate preventive measures.

So, the clinical and genealogical analysis of pedigrees of patients with FRO cancer has established accumulation of tumor pathology in the form of family cancer syndrome and hereditary forms of $\mathrm{OC}$ and BC. According to the results of molecular-genetic examination of patients with benign pathology and FRO cancer after an analysis of intergene interaction in groups of patients with benign and malignant pathology of FRO and control group, it was established that the polymorphic variants of ESR1 gene had a major influence on the development of the pathology.

The best predictive accuracy for the evaluation of the risk of benign tumors of the FRO $(71.68 \%)$ and the highest significance $(p<0.001)$ was the model, which included the polymorphic variants of the T397C(ESR1)/CYP 2D6*4 genes. At the same time, all established models of intergene interaction in the development of malignant pathology of $\mathrm{FRO}$ were reli- able, prognostically significant with high reproduction and almost identical accuracy (65.00-68.23\%).

The obtained results indicate a high informativeness of such molecular genetic indices as the polymorphism of ESR 1 and CYP 2D6*4 genes and mutations in $B R C A 1 / 2$ genes to assess the risk of benign or malignant tumors of FRO in families of patients with family history of cancer. This gives the right to recommend the described molecular genetic models for practical use in oncology to assess the risk of benign and malignant pathology in families in which, according to genealogical data, aggregation of malignant tumors has been identified.

\section{ACNOWLEDGEMENT}

The work was carried out within the framework of the scientific project "Molecular-biological factors of heterogeneity of malignant cells and the variability of the clinical course of hormone-dependent tumors" (2017-2021, No. of State Registration 0117U002034).

\section{REFERENCES}

1. Hsieh CC, Trichopoulos D, Katsouyanni K, et al. Age at menarche, age at menopause, height and obesity as risk factors for breast cancer: associations and interactions in an international case-control study. Int J Cancer 1990; 46: $796-800$.

2. Hartmann LC, Sellers TA, Frost MH, et al. Benign breast disease and the risk of breast cancer. N Engl J Med 2005; 353: 229-37.

3. Martin LJ, Minkin S, Boyd NF. Hormone therapy, mammographic density, and breast cancer risk. Maturitas 2009; 64: 20-6.

4. Kamińska M, Ciszewski T, Łopacka-Szatan K, et al. Breast cancer risk factors. Prz Menopauzalny 2015; 14: 196-202.

5. Knudson AG. Two genetichits (more or less) to cancer. Nat Rev Cancer 2001; 1: 157-62.

6. Chanock S. Candidate gene sand single nucleotide polymorphisms (SNPs) in the study of human disease. Dis Markers 2001; 17: 89-98.

7. Sapkota Y. Germline DNA variations in breast cancer predisposition and prognosis: asystematice view of the literature. Cytogenet Genome Res 2014; 144: 77-91.

8. http://www.sciencedirect.com/science/article/pii/ S0300908401013633 - COR1.

9. Manchanda R, Loggenberg K, Sanderson S, et al. Population testing for cancer predisposing BRCA1/BRCA2 mutations in the Ashkenazi-Jewish community: a randomized controlled trial. J Natl Cancer Inst 2015; 107: 379.

10. Antoniou AC, Beesley J, McGuffog L, et al. Common breast cancer susceptibility allels and the risk of breast cancer for BRCA1 and BRCA2 mutation carriers: implication for risk prediction. Cancer Res 2010; 23: 9742-54.

11. Li J, Peng Y, Liu H, Wu Q. The association between CCR5 32 polymorphism and susceptibility to breast cancer. Oncotarget 2017; 8: 82796-802.

12. Oosterwijk JC, de Vries J, Mourits MJ, et al. Genetic testing and familial implications in breast-ovarian cancer families. Maturitas 2014; 78: 252-7.

13. Chanock S. Candidate gene sand single nucleotide polymorphisms (SNPs) in the study of human disease. Dis Markers 2001; 17: 89-98.

14. Milne RL, Benítez $J$, Nevanlinna $H$, et al. Risk of estrogen receptor-positive and -negative breast cancer and 
single-nucleotide polymorphism 2q35-rs13387042. J Natl Cancer Inst 2009; 101: 1012-8.

15. Lyubchenko NL, Filippova NG, Shendriva TA, et al. Pharmacogenetic testing of allelic variants of the CYP2D6 gene in hormone-positive breast cancer. Uspekhi Mol Oncol 2017; 4: 57-66 (in Russian).

16. Meisel SF, Side L, Fraser L, et al. Population-based, risk-stratified genetic testing for ovarian cancer risk: a focus group study. Public Health Genomics 2013; 16: 184-91.

17. Meisel SF, Rahman B, Side L, et al. Genetic testing and personalized ovarian cancer screening: asurvey of public attitudes. BMC Womens Health 2016; 16: 46.

18. Jones $\mathrm{S}$, Anagnostou V, Lytle $\mathrm{K}$, et al. Personalized genomic analyses for cancer mutation discovery and interpretation. Sci Transl Med 2015; 7: 253-83.

19. Tuxen IV, Jonson L, Santoni-Rugiu E, Hasselby JP, et al. Personalized oncology: genomic screening in phase 1. Apmis 2014; 122: 723-33.

20. Matsuno RK, Costantino JP, Ziegler RG, et al. Projecting individualized absolute invasive breast cancer risk in Asian and Pacific Islander American women. J Natl Cancer Inst 2011; 103: 951-61.

21. Dite GS, Mahmoodi M, Bickerstaffe A, et al. Using SNP genotypes to improve the discrimination of a simple breast cancer risk prediction model. Breast Cancer Res Treat 2013; 139: 887-96.

22. Husing A, Canzian F, Beckmann L, et al. Prediction of breast cancer risk by genetic risk factors, overall and by hormone receptor status. J Med Genet 2012; 49: 601-8.
23. Paliychuk OV, Polystchuk LZ, Rossokha ZI, Chekhun VF. Investigation of ESR1 gene polymorphisms in patients with cancer of the female reproductive system with a burdened family history. Onkologiya 2016; 21 : 31624 (in Ukrainian).

24. Motsinger AA, Ritchie MD. Multifactor dimensionality reduction: analysis strategy for modelling and detecting gene-gene interactions in human genetics and pharmacogenomics studies. Hum Genomics 2006; 2: 318-28.

25. Arnedos M, Vielh P, Soria JC, Andre F. Genetic complexity of common cancers and the promise of personalized medicine: is there any hope? J Pathol 2014; 232: 274-84.

26. Blair BG, Bardelli A, Park BH. Somatic alterations as the basis for resistance to targeted therapies. J Pathol 2014; 232: $244-54$.

27. Yang D, Khan S, Sun Y, et al. Association of BRCA1 and BRCA2 mutations with survival, chemotherapy sensitivity, and gene mutatorphenotype in patients with ovarian cancer. JAMA 2011; 306: 1557-65.

28. Pennington KP, Walsh T, Harrell MI, et al. Germline and somatic mutations in homologous recombination gene spredict platinum response and survival in ovarian, fallopian tube, and peritoneal carcinomas. Clin Cancer Res 2014; 20: 764-75.

29. Sakai W, Swisher EM, Karlan BY, et al. Secondary mutations as a mechanism of cisplatin resistance in BRCA2mutated cancers. Nature 2008; 451: 1116-20.

30. Klement GL, Arkun K, Valik D, et al. Future paradigms for precision oncology. Oncotarget 2016; 7: 46813-31. 